\title{
Antecedents of organizational commitment among faculty: an exploratory study
}

Andrey Lovakov

Center for Institutional Studies, National Research University Higher School of Economics, Moscow, Russia

Correspondence details: International Laboratory for Institutional Analysis of Economic Reforms (LIA), Center for Institutional Studies, National Research University Higher School of Economics, 20 Myasnitskaya Ulitsa, Moscow 101000, Russia, lovakov@hse.ru

This is the author's version of an published article. It may be cited as follows:

Lovakov, A. (2016). Antecedents of organizational commitment among faculty: an exploratory study. Tertiary Education and Management, 22(2), 149-170. http://doi.org/10.1080/13583883.2016.1177583 
Faculty are the main asset of a university and determine its success. The attitudes of faculty toward their institution play an especially important role in the academic profession. This study examines the specific antecedents of affective, normative and continuance commitment of faculty to their university. This study is an online survey of 317 faculty of Russian higher education institutions. The results of the regression analysis showed that being an undergraduate inbred (ie, working at the university from which one graduated) predicted affective and normative commitment toward the university, while having a post at another higher education institution predicted only affective commitment. Also, faculty who work at several universities have lower levels of emotional attachment to the primary university.

Keywords: organizational commitment; academic inbreeding; faculty; academic profession; universities 


\section{Introduction}

Faculty are the main asset of a university and determine its success. The work of faculty is diverse and uncertain, and it is hard to fully describe and formally regulate (for characterization of the academic profession see Shattock, 2014). Therefore their performance is largely determined by their job involvement and willingness to do more than is formally described in their contracts and job responsibilities (working on weekends, helping colleagues to perform a variety of extracurricular activities, etc.). Neumann and Finaly-Neumann (1990, p. 77) note that

Universities need dedicated faculty members who not only join their university but continue to remain actively involved in innovative research activities; prepare new materials and approaches for teaching; build, assess, and reform academic programs; maintain high levels of academic standards; participate in academic decision making; and work closely and actively with their students.

But why do some faculty get more involved in the affairs of the university, personally experiencing its failures and enjoying its successes, than others who do not? Numerous studies show that faculty attitudes about their institution play an especially important role in this case (Chughtai \& Zafar, 2006; Daly \& Dee, 2006; Eisinga, Teelken, \& Doorewaard, 2010; Jing \& Zhang, 2014). There is a special psychological bond between employees and the organization, which determines their work and organizational behaviour. This psychological bond may be expressed by the commitment the employee feels toward the organization (Abrams, Ando, \& Hinkle, 1998; Allen \& Meyer, 1990; O’Reilly \& Chatman, 1986). Research suggests organizational commitment is one of the main predictors of such extra-role behaviour. Workers who have strong commitment to the organization see their job more positively, want to stay in the organization, and are more satisfied and involved with their job (Meyer, Stanley, Herscovitch, \& Topolnytsky, 2002). In other words, a worker with high commitment is a 'good soldier' for the organization. Most research on organizational commitment has been carried out in business organizations, but different types of organizations, such as universities, have specific features that distinguish them from others. As in the case 
of other non-profit organizations, faculty values and attitudes are particularly important for the functioning of the university. Baldridge (1983) identified specific features, such as goal ambiguity, highly contested goals, client-serving institutions, problematic technologies, high professionalism, fragmented professional staff, and environmental vulnerablenessle. A university's levels of fragmentation (Baldridge, 1983) and complexity (Duderstadt, 2001) are the key characteristics for the faculty commitment because the university as a focus for commitment may be quite difficult. This study explores three specific antecedents of faculty commitment to their university (chosen by the author as subjects of particular research interest): academic inbreeding, simultaneous work in several higher education institutions (HEIs), and combining teaching and administrative positions.

\section{The concept of the organizational commitment}

The concept of 'organizational commitment' is widespread in organizational behavior and management literature. In general, commitment to the organization is a psychological attitude referring to an employee's desire to stay in the organization, to be a good worker, and to make maximum efforts in the interests of the organization (Mowday, Porter, \& Steers, 1982). However, commitment may have different bases. Allen and Meyer (1990) propose a three-component model of organizational commitment: 1) affective commitment, which refers to the employee's emotional attachment to, identification with, and involvement in the organization; 2) continuance commitment, which refers to an awareness of the costs associated with leaving the organization; and 3) normative commitment, which refers to a feeling of obligation to continue employment in the same organization. In other words, an employee with a strong affective commitment wants to stay in the organization, an employee with a strong continuance commitment needs to stay in the organization, and an employee with a strong normative commitment feels he or she ought to stay in the organization. This model has received empirical support in higher education settings (Eisinga et al., 2010; Gutierrez, Candela, \& Carver, 2012). 
A high level (primarily affective commitment) is associated with a number of favorable consequences for both the organization and the worker. Meta-analyses indicate that affective and normative commitment are positively related to job satisfaction, job involvement, organizational citizenship behavior, and performance, and negatively related to intention to leave, and voluntary absenteeism (Cooper-Hakim \& Viswesvaran, 2005; Mathieu \& Zajac, 1990; Meyer et al., 2002). Affective commitment is also related to the employee's physical and psychological well-being (Meyer \& Maltin, 2010). Research in higher education settings shows that affective commitment is an important element in retaining a high-performance academic workforce (Eisinga et al., 2010).

\section{Antecedents of organizational commitment among university faculty}

A number of studies conducted in academia show that the organizational commitment of teaching staff has similar antecedents to that of employees in business (organizational justice, job insecurity, trust in the university's management, perceived organizational support, perceived organizational prestige) (Adkins, Werbel, \& Farh, 2001; Ambrose \& Cropanzano, 2003; Fuller, Hester, Barnett, \& Relyea, 2006; Li, 2014). Tahir, Abdullah, Ali, and Daud (2014) found heads of departments' transformational leadership behaviours have an impact on the organisational commitment of academic staff. However, teaching staff have specific antecedents of organizational commitment. Neumann and Finaly-Neumann (1990) found that the commitment of faculty to their university is stronger in fields where several career alternatives for example, an academic career or a job in business - exist (eg 'applied fields' such as education and electrical engineering) and considerably weaker in fields where career alternatives are restricted (eg 'pure fields' such as physics and sociology). Graduates from pure fields have fewer alternatives, so they are more frequently forced to choose an academic career and may not enjoy the same amount of choice. Affective commitment is also stronger when teaching staff have plenty of time to learn new tasks and are encouraged to express their ideas and opinions openly (Southcombe, Fulop, Carter, \& Cavanagh, 2014). Antecedents of normative commitment include academic tenure (Adkins et al., 2001); antecedents of 
continuance commitment include academic rank, organizational tenure and employment status (full time or part time) (Marchiori \& Henkin, 2004). However, the academic profession and universities as organizations have more specific features that distinguish them from other types of organizations (Musselin, 2013). The current study focused on three of them: academic inbreeding, academic experience in another university, and combining teaching and administrative positions.

\section{Academic inbreeding}

Universities have the opportunity to hire their own graduates. In the literature this phenomenon is called 'academic inbreeding' (for literature review see Gorelova \& Yudkevich, 2015). According to this

criterion, faculty can be divided into two groups: inbreds who work at the same university from which they graduated, and non-inbreds who are not graduates of the university where they work. There are some differences between them in the literature.

Inbreds often have no experience at another university and have a longer history with their university that is more emotive and positive. This should all contribute to inbreds' strong emotional ties with the university and dedication to it. In universities where academic inbreeding is common practice, social ties between a graduate and the professor/supervisor or department head play a decisive role in the process of hiring (Horta, Sato, \& Yonezawa, 2011). This means that, in the case of the inbreds, the hiring process may be based on social ties with their supervisor and the university administration rather than on a standardized evaluation of their academic performance. Eisenberg and Wells (2000) mention that professors may hire their own graduates because they have performed well and are interested in their area, participated in their projects, and have views close to those of the professor. As result, inbreds concentrate their communication most within their universities (Horta, 2013). The practice of hiring inbreeds is widespread in Russia. Formally, the hiring process is open and competitive. Universities should make information about a new position known both publicly and nationally, and they mostly do so. However, usually only internal candidates participate in the hiring process. External candidates usually do not even 
apply, because they have very little chance of being hired (Sivak \& Yudkevich, 2015). Some universities have begun using genuinely open and competitive hiring only relatively recently. According to the data from the 'Changing Academic Profession' (CAP) survey, 64\% of all academics in Russia work in the same institution at which they studied at least at one of the educational levels (Yudkevich, Kozmina, Sivak, Bain, \& Davydova, 2013). Usually, Russian postgraduate students who graduated from the same HEI at which they study simultaneously conduct their research toward their dissertation and carry out teaching (having a teaching position and assisting their mentor who, usually, invites them to apply to the graduate school and offers them a position) (Sivak \& Yudkevich, 2015). Sivak and Yudkevich (2015) also report on an additional particular aspect of Russian academia - so-called 'scientific schools'. A scientific school is basically a chair system. This is a group of researchers united around one or more famous (mostly nationally but possibly just within the institutional) professors who work within the same topic or theoretical framework. This group exists for a long time and attracts students and alumni as young researchers and faculty. Very often, such a scientific school is the only way for young researchers to get into academia and achieve promotion within it. Moreover, members of such scientific schools identify themselves very strongly with the school. Such scientific schools are often affiliated with a university or research institution; consequently belonging to such a school means belonging to the institution as well, and may also contribute to commitment toward this institution. Based on the analysis of interview with rectors, vice-rectors, deans and department chairs of several Russian universities, Horta and Yudkevich (2015) concluded that having good relationships with seniors is a essential condition of younger academics' career progression. Therefore this hiring system selects candidates who initially may be more devoted and loyal to the university, integrated with it in social networks, and identity with it (Horta \& Yudkevich, 2015; Vázquez-Cupeiro \& Elston, 2006). Inbreds may feel indebted to professors and feel affective and normative commitment to their department and to the university as whole.

One more feature of the Russian academic labor market, which affects academic inbreeding practice, is a low level of academic mobility. It is rather difficult for young faculty to move to another city 
because of low starting salaries and poor social infrastructure (Sivak \& Yudkevich, 2015). This situation forces them to stay in their home city or the city where they graduated from university and try to get a position at that location. After obtaining a position, they remain working at that institution for a long time, especially in small towns due to the lack of another HEI. According to data of the international comparative CAP survey, only $26 \%$ of Russian faculty said that they have been employed in two or more institutions since their first degree (Yudkevich et al., 2013). Therefore inbreds may feel difficulties associated with leaving their university and have a continuance commitment to it.

Hypotheses 1-3: Being an inbred is a positive predictor of the level of affective, continuance, and normative commitment to the HEI.

\section{Academic experience in another university}

In academia, faculty are able to work in several HEIs. This is common practice for Russian faculty because of low wages (Yudkevich, 2014). According to an international comparative study, the salaries of Russian faculty are among the lowest (Altbach, Reisberg, Yudkevich, Androushchak, \& Pacheco, 2012). The most common way to compensate for low wages is by teaching at another institution (in addition to a full-time position at the main institution) (Roschina \& Filippova, 2006). There is the term 'conflict of commitment', which refers to conflicts of interest, time and energy related to both jobs (Euben, 2004). Working in several institutions simultaneously gives someone the opportunity to get different experiences and compare conditions, and provides multiple group memberships. From a psychological point of view, membership of several groups leads to an awareness of belonging to each of them. The characteristics of each of these organizations define the employee's identity (Ashforth \& Johnson, 2003; Becker, 1992). This situation creates a potential identity conflict, which is more likely if there is an inconsistency between the contents of these identities (a mismatch or even a clash of values, goals, or norms). The experience of identity conflict may ultimately impair identification with one or more organizations (Ashforth, Harrison, \& Corley, 2008). Whereas identification with an organization overlaps with affective 
organizational commitment (Riketta, 2005), it is expected that there is a relationship between simultaneous work in several HEIs and the affective commitment to the primary university (the university in which a respondent spends the most time). Simultaneous work in several institutions may also decrease the perceived transition costs from one employer to another. Sinclair, Martin, and Michel (1999) found that moonlighters (employees who were employed part-time in a second job) tended to be less committed, less dependent on the employment relationship and perceived better employment alternatives than the fulltimers. It is expected that there is a relationship between working simultaneously in several HEIs and the continuance commitment to the university.

Hypotheses 4-5: Simultaneous work in several HEIs is a negative predictor of the level of affective and continuance commitment.

\section{Combining several positions}

Faculty have the opportunity to combine several professional roles (teaching, administrative, research), which are often distributed among different employees in other types of organizations. In the USSR, research was carried out mainly in scientific institutions, which were parts of the Academies of Science. Universities were called upon to prepare their staff for scientific and professional activity. Nowadays, this situation is changing and such universities have also started carrying out research (Yudkevich, 2014), but a large section of the faculty are still not interested in research. According to the Changing Academic Profession survey (2012), only 37\% of faculty are interested primarily in research activities (Kozmina, 2014). It means that combining teaching and research positions is not necessarily common. For this reason, teaching and administrative positions were studied. Faculty who have a second administrative position devote a portion of their career in service to the department and the faculty, are more involved in the university's life, and spend more time at work (Gmelch \& Burns, 1994; Hancock, 2007). This leads to their greater job involvement. Previous research shows that job involvement is positively associated with affective commitment (Meyer et al., 2002). In the role of the administrator, they act on behalf of the 
university and implement its goals and objectives. Acceptance of this role is an additional reason to identify themselves with the university, which in turn is the basis for affective commitment (Edwards, 2005). Nevertheless, there may be a reciprocal relationship between combining teaching and administrative positions and affective commitment. A high level of affective commitment may be the reason for management to appoint faculty to an administrative position. Also, combining teaching and administrative positions may lead to higher affective commitment. However, in the literature, a job's characteristics are traditionally considered as predictors, but commitment is considered as a reaction to these characteristics (Meyer et al., 2002). Regardless of the causal direction, we can expect a positive relationship between combining teaching and administrative posts and the affective commitment of faculty.

Hypothesis 6: Combining teaching and administrative positions is associated with affective commitment to the HEI.

\section{Method}

\section{Participants and procedure}

The data were collected via an online questionnaire. Invitations to participate in the survey were distributed to subscribers of several Russian journals and to groups in social networks devoted to education and academia, and through personal networks of the author and colleagues. Before the survey began, the respondents were informed about the purpose and procedure, and their right to withdraw from the study at any time. The survey was anonymous and the respondents were informed that their answers would be kept confidential and used only for research purposes. The survey involved 317 Russian faculty (109 men, 208 women). The mean age was 41.57 years $(S D=11.24$ years); one participant did not specify their age. The total length of teaching experience in academia was 20.51 years $(S D=11.34$ years) and the average job tenure in the current HEI was 11.72 years $(S D=8.03$ years $)$. The sample included $17 \%$ professors, $56 \%$ associate professors, $15 \%$ senior lecturer, $5 \%$ lecturer, and $7 \%$ assistants. The sample 
represented faculty from different disciplines: economics $34 \%$, other social sciences $44 \%$, natural sciences $5 \%$, engineering $9 \%$, humanities $16 \%$, mathematics and cybernetics $13 \%$, other $4 \%$ (the sum is more than $100 \%$ because some of the participants teach in disciplines from several groups). Participants represented 119 institutions, but $67.5 \%$ of them are from 30 institutions.

\section{Limitations}

This study is not without limitations. The first limitation is the small and non-random sample. The invitation to participate in the survey was distributed to subscribers of several magazines about education, through thematic groups in social networks, and through the author's and his colleagues' personal networks. This approach to invitation could lead to selection bias. Among the participants of the survey there could be significantly more faculty with a higher level of job involvement and professional commitment because they are more involved in activities related to the academic profession. For this reason, the current study should be regarded as exploratory and non-generalizable to all Russian faculty. It is intended to delve more deeply into the experiences of faculty lives and provide meaning to those experiences. A second limitation is that the sample includes faculty of different disciplines, but the number of faculty from each discipline is insufficient for a comparison between them. Such analysis would be useful because Neumann and Finaly-Neumann (1990) showed that teachers of different disciplines may differ in their level of the commitment to their university. Thirdly, participants are from different cities where academic labor market can be different. The labor supply may be severely restricted in some of them because of the small number of HEIs. As mentioned above, it is rather difficult for faculty (and not only for faculty) to move to another city. Such limitations may affect the continuance commitment to a university and create an additional variation. To overcome this, HEIs' locations were controlled by separating Moscow and St. Petersburg (Russia's two largest cities and those with the greatest number of HEIs) from the rest. However, such differentiation can be crude. 


\section{Dependent variables}

Three components of the organizational commitment were dependent variables. Affective, continuance and normative commitment were measured by nine items (three items for each scales) from the Organizational Commitment Scale (OCS) (Allen \& Meyer, 1990). All items employed a 7-point Likertscale. The items were translated from English into Russian by the author. Translation of all measures (including those described below) was discussed with a bilingual person, who was unaware of the subject of the study. Differences in translations were discussed until agreement was reached. Confirmatory factor analysis (MLR estimator) was conducted to test the factor structure reproducibility of the Russian translation. The 3-factor theoretical model (three items on each latent variable) fitted well to the empirical data: $\chi^{2}=25.42(p=.33), d f=23, \mathrm{CFI}=.99, \mathrm{TLI}=.99, \mathrm{RMSEA}=.02$, [95\% CI: .00-.05], SRMR $=.03$. The short Russian version of the OCS has a similar 3-factor structure: three components of the commitment to HEI can be considered as independent scales (Cronbach's alpha range from .66 to .80).

\section{Independent variables}

Academic inbreeding. There are several methods for the operationalization of academic inbreeding, of which two were used. Faculty were considered as inbreds 1) if they were working in the HEI where they received their bachelor degree or diploma (undergraduate inbred), and 2) if they were working in the HEI where they received a Candidate of Sciences degree, which is the Russian equivalent of the international $\mathrm{PhD}$ degree (postgraduate inbred). Berelson (1960) argued that it is necessary to separate the faculty working in the same university where they graduated and who were hired immediately following graduation (pure inbreds) from faculty working in the same university where they graduated, but who had taken positions elsewhere after graduating (silver-corded). Recent research show the differences between pure inbreds and silver-corded faculty (Horta, 2013; Morichika \& Shibayama, 2015). Inbreds and silvercorded faculty were divided using information about the early years of their work in academia and in their current university (in which a respondent spends the most time). If these years were the same, the faculty 
was regarded as an inbred; if not, as silver-corded. According to these criteria, the sample contained 128 (40.4\%) undergraduate inbreds and 23 (7.3\%) undergraduate silver-corded faculty, 98 (30.9\%)

postgraduate inbreds and $10(3.2 \%)$ postgraduate silver-corded faculty.

Academic experience in another university was measured by the question: Have you worked at another HEI in the current year additionally? According to the answers to this question, 129 (40.7\%) participants were classified as working at several institutions.

Combining teaching and administrative positions was measured by the question: What positions do you have in the university? If a participant had one teaching position (professor, assistant professor, senior lecturer, lecturer, assistant) and at least one administrative position (rector, vice-rector, dean, deputy dean, head of department, head of lab, manager or coordinator), he or she was considered to be combining the positions. There were $81(25.6 \%)$ participants in the sample who combined teaching and administrative positions.

\section{Statistical analysis}

Hypotheses were tested using an ordinary least-squares regression in R (R Core Team, 2015). For each of the three types of organizational commitment, regression models were built in which the dependent variable was one of the types of commitment. Several control variables were used. Demographic variables (gender, age) were controlled. Academic seniority (dummies for professors and associate professors) was also controlled because it is likely that the more senior one's rank in a university, the more one is engaged in an administrative position. The locations of institutions was an additional control variable, because commitment (especially continuance commitment) can be affected by objective characteristics of the academic labor market which are different in big and small cities; Moscow and St. Petersburg were therefore separated from other cities. The quality of the university may also affect the attachment of faculty. For this reason, university quality was controlled by two variables: 1) a dummy, 
which differentiated universities with special statuses ('national research university' and 'federal universities') from all other universities, because these statuses reflect the effectiveness of the educational process and its integration with scientific research; 2) mean scores of the Unified State Exam of students who were enrolled in full-time bachelor and diploma programs (data from monitoring the effectiveness of educational institutions of higher education, which was conducted by the Russian Ministry of Education and Science in 2014: http://miccedu.ru/monitoring/2014/). Teaching and administrative positions are different, require different competencies and can even compete with each other. This may lead someone to feel role conflict. Role conflict refers to the incongruence or incompatibility of the requirements of one role or between different roles (Rizzo, House, \& Lirtzman, 1970). Previous research shows that role conflict is a significant antecedent of low affective commitment (Meyer et al., 2002). Emotional attachment as a basis for affective commitment may be challenged by this factor. Research in higher education area also shows a negative relationship between role conflict and affective commitment (Gormley \& Kennerly, 2010; Schulz, 2013; Wolverton, Wolverton, \& Gmelch, 1999). Role conflict measured by a scale from the General Nordic Questionnaire for Psychological and Social Factors at Work (Dallner et al., 2000) was entered in all models as a control variable. The role conflict scale consist of three items (e.g. 'Do you have to do things that you feel should be done differently?') and employed a 5point Likert-scale, ranging from 1 (very seldom or never) to 5 (very often or always). Job satisfaction, measured by the Brief Index of Affective Job Satisfaction (BIAJS) (Thompson \& Phua, 2012), was also included in all models because of the strong association between commitment and job satisfaction (Meyer et al., 2002). BIAJS consists of four items (e.g. 'I like my job better than the average person') with three distracter items (e.g. 'My job is unusual') not used in analyses. All items employed a 5-point Likert-scale, ranging from 1 (totally disagree) to 5 (totally agree). Hierarchical regression analysis was conducted. Control variables were entered at the first step of the regression equation as covariates. Dummies for two types of academic inbreeding, working at several HEIs, and combining teaching and administrative positions were entered separately at the second step. At the third step, all independent variables were 
entered. Table 1 shows the descriptive statistics and Cronbach's alphas (when possible). Table 2 shows correlations between used variables.

Table 1. Descriptive statistics of variables.

\begin{tabular}{llcccc}
\hline & $M$ & $S D$ & Min & Max & $\begin{array}{c}\text { Cronbach's } \\
\text { alphas }\end{array}$ \\
\hline 1. Affective commitment & 5.01 & 1.29 & 1 & 7 & .70 \\
2. Continuance commitment & 3.39 & 1.42 & 1 & 7 & .66 \\
3. Normative commitment & 3.52 & 1.45 & 1 & 7 & .80 \\
4. Undergraduate inbred (1-yes) & .40 & - & 0 & 1 & - \\
5. Undergraduate silver-corded (1-yes) & .07 & - & 0 & 1 & - \\
6. Postgraduate inbred (1-yes) & .31 & - & 0 & 1 & - \\
7. Postgraduate silver-corded (1-yes) & .03 & - & 0 & 1 & - \\
8. Working at several HEIs (1-yes) & .41 & - & 0 & 1 & - \\
9. Combining teaching and administrative positions (1-yes) & .26 & - & 0 & 1 & - \\
10. Gender (1-male) & .34 & - & 0 & 1 & - \\
11. Age & 41.57 & 11.24 & 23 & 78 & - \\
12. Professor (1-yes) & .17 & - & 0 & 1 & - \\
13. Associate professor (1-yes) & .58 & - & 0 & 1 & - \\
14. Job satisfaction & 3.40 & 0.71 & 1 & 5 & .82 \\
15. Role conflict & 3.12 & 0.93 & 1 & 5 & .81 \\
16. University status (1-federal/national research) & .38 & - & 0 & 1 & - \\
17. University location (1-Moscow or St. Petersburg) & .35 & - & 0 & 1 & - \\
18. Mean USE & 75.97 & 11.99 & 0 & 100 & - \\
\hline
\end{tabular}


Table 2. Correlation matrix.

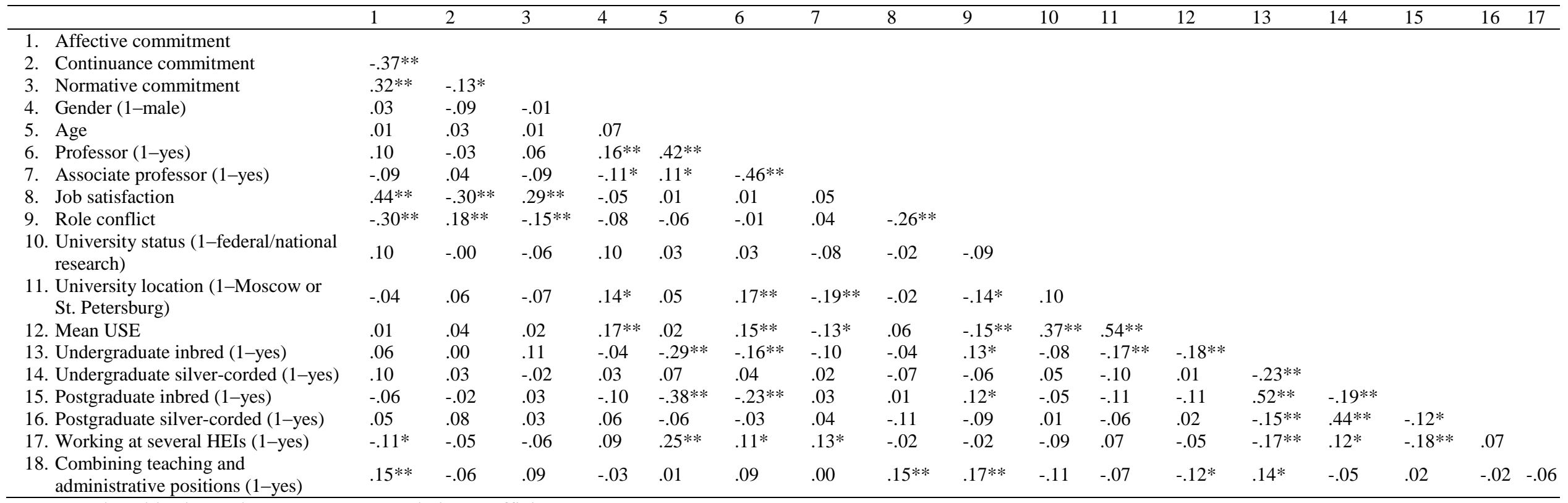

Note. The table shows the Spearman's correlation coefficients. $* p<.05 ; * * p<.01$. 


\section{Results}

As shown in Tables 3-5, undergraduate inbreeding significantly predicted affective (model 2: $B=0.305, p$ $=.041$ ) and normative (model 14: $B=0.402, p=.021$ ) commitment. But the effect of undergraduate inbreeding on affective commitment was not robust and disappeared after including dummies for working at several HEIs and combining teaching and administrative positions (model 6: $B=0.241, p=.105$ ), whereas the effect on normative commitment continued to be significant (model 18: $B=0.376, p=.036$ ). There were no differences between undergraduate inbreds and non-inbreds on the level of the continuance commitment (model 8: $B=0.067, p=.704$; model 7 vs model 8 LRT $\chi^{2}=0.76, p=.685$ ). Postgraduate inbreeding did not predict any of the three components of commitment (see models 3, 9, 15). Belonging to undergraduate silver-corded faculty also significantly predicted affective commitment (model 2: $B=$ $0.675, p=.004)$. This effect was robust and continued to be significant after the inclusion of dummies for working at several HEIs and combining teaching and administrative positions (model 6: $B=0.732, p=$ .003). Thus, undergraduate inbreds had a higher level of normative organizational commitment compared to undergraduate non-inbreds, whereas undergraduate silver-corded faculty had a higher level of affective organizational commitment. Hypotheses 1 and 3 were partly supported, whereas hypothesis 2 was not.

Contrary to expectations, having an additional job at another HEI significantly predicted only affective commitment (model $4: B=-0.303, p=.035$ ), and this effect was robust (model 6: $B=-.289, p$ $=.043)$. But the link between having an additional job at another HEI and continuance commitment was not statistically significant (model 10: $B=-.231, p=.191$ ). Thus, faculty working at several HEI showed lower-level affective commitment toward their primary HEI. Hypothesis 4 was supported, but hypothesis 5 was not.

According to the results, the dummy for combining teaching and administrative positions was a significant predictor of affective commitment (model 5: $B=-0.396, p=.011$ ). This effect was significant even in the case of controlling for perceived role conflict and after including dummies for undergraduate 
inbreeding, silver-corded faculty, and working at several HEIs (model 6: $B=0.353, p=.022$ ). Faculty who combined teaching and administrative positions had a higher level of affective commitment compared to the rest of the faculty. Hypothesis 6 was supported. Additional mediation analysis (Sobel test) showed that role conflict is a mediator for the relationship between combining teaching and administrative positions and affective commitment to the university. The total direct effect of combining teaching and administrative positions on affective commitment was .39 ( $p=.017)$, and direct effect removing role conflict was $.57(p<.001)$. Therefore, indirect effect combining teaching and administrative positions on affective commitment through role conflict was $-.17(95 \% \mathrm{CI}=-.31 \ldots-.06)$.

Table 3. Predictors of the affective commitment.

\begin{tabular}{|c|c|c|c|c|c|c|}
\hline & Model 1 & Model 2 & Model 3 & Model 4 & Model 5 & Model 6 \\
\hline Gender (1-male) & $\begin{array}{l}0.067 \\
(0.138)\end{array}$ & $\begin{array}{l}0.053 \\
(0.135)\end{array}$ & $\begin{array}{l}0.049 \\
(0.137)\end{array}$ & $\begin{array}{l}0.093 \\
(0.138)\end{array}$ & $\begin{array}{l}0.060 \\
(0.136)\end{array}$ & $\begin{array}{l}0.072 \\
(0.133)\end{array}$ \\
\hline Age & $\begin{array}{l}-0.002 \\
(0.007)\end{array}$ & $\begin{array}{l}-0.001 \\
(0.007)\end{array}$ & $\begin{array}{l}-0.002 \\
(0.007)\end{array}$ & $\begin{array}{l}-0.000 \\
(0.007)\end{array}$ & $\begin{array}{l}-0.002 \\
(0.007)\end{array}$ & $\begin{array}{l}0.002 \\
(0.007)\end{array}$ \\
\hline Professor (1-yes) & $\begin{array}{l}0.298 \\
(0.234)\end{array}$ & $\begin{array}{l}0.329 \\
(0.243)\end{array}$ & $\begin{array}{l}0.275 \\
(0.234)\end{array}$ & $\begin{array}{l}0.334 \\
(0.237)\end{array}$ & $\begin{array}{l}0.232 \\
(0.238)\end{array}$ & $\begin{array}{l}0.291 \\
(0.253)\end{array}$ \\
\hline Associate professor (1-yes) & $\begin{array}{l}-0.157 \\
(0.157)\end{array}$ & $\begin{array}{l}-0.138 \\
(0.165)\end{array}$ & $\begin{array}{l}-0.200 \\
(0.157)\end{array}$ & $\begin{array}{l}-0.126 \\
(0.160)\end{array}$ & $\begin{array}{l}-0.201 \\
(0.157)\end{array}$ & $\begin{array}{l}-0.110 \\
(0.168)\end{array}$ \\
\hline Job satisfaction & $\begin{array}{l}0.698 * * * \\
(0.094)\end{array}$ & $\begin{array}{l}0.727 * * * \\
(0.090)\end{array}$ & $\begin{array}{l}0.719 * * * \\
(0.093)\end{array}$ & $\begin{array}{l}0.693 * * * \\
(0.094)\end{array}$ & $\begin{array}{l}0.661 * * * \\
(0.094)\end{array}$ & $\begin{array}{l}0.692 * * * \\
(0.090)\end{array}$ \\
\hline Role conflict & $\begin{array}{l}-0.295^{* * * *} \\
(0.072)\end{array}$ & $\begin{array}{l}-0.287 * * * \\
(0.072)\end{array}$ & $\begin{array}{l}-0.280^{* * * *} \\
(0.074)\end{array}$ & $\begin{array}{l}-0.294 * * * \\
(0.072)\end{array}$ & $\begin{array}{l}-0.332 * * * \\
(0.073)\end{array}$ & $\begin{array}{l}-0.316^{* * *} \\
(0.070)\end{array}$ \\
\hline $\begin{array}{l}\text { University status ( } 1- \\
\text { federal/national research) }\end{array}$ & $\begin{array}{l}0.137 \\
(0.141)\end{array}$ & $\begin{array}{l}0.141 \\
(0.141)\end{array}$ & $\begin{array}{l}0.135 \\
(0.141)\end{array}$ & $\begin{array}{l}0.114 \\
(0.140)\end{array}$ & $\begin{array}{l}0.151 \\
(0.141)\end{array}$ & $\begin{array}{l}0.127 \\
(0.140)\end{array}$ \\
\hline $\begin{array}{l}\text { University location (1-Moscow or } \\
\text { St. Petersburg) }\end{array}$ & $\begin{array}{l}-0.174 \\
(0.137)\end{array}$ & $\begin{array}{l}-0.076 \\
(0.143)\end{array}$ & $\begin{array}{l}-0.161 \\
(0.138)\end{array}$ & $\begin{array}{l}-0.145 \\
(0.140)\end{array}$ & $\begin{array}{l}-0.176 \\
(0.135)\end{array}$ & $\begin{array}{l}-0.055 \\
(0.146)\end{array}$ \\
\hline Mean USE & $\begin{array}{l}-0.004 \\
(0.006)\end{array}$ & $\begin{array}{l}-0.004 \\
(0.006)\end{array}$ & $\begin{array}{l}-0.004 \\
(0.006)\end{array}$ & $\begin{array}{l}-0.004 \\
(0.006)\end{array}$ & $\begin{array}{l}-0.002 \\
(0.006)\end{array}$ & $\begin{array}{l}-0.003 \\
(0.006)\end{array}$ \\
\hline Undergraduate inbred (1-yes) & & $\begin{array}{l}0.305^{*} \\
(0.149)\end{array}$ & & & & $\begin{array}{l}0.241 \\
(0.148)\end{array}$ \\
\hline $\begin{array}{l}\text { Undergraduate silver-corded (1- } \\
\text { yes) }\end{array}$ & & $\begin{array}{l}0.675^{* *} \\
(0.231)\end{array}$ & & & & $\begin{array}{l}0.732 * * \\
(0.243)\end{array}$ \\
\hline Postgraduate inbred (1-yes) & & & $\begin{array}{l}-0.065 \\
(0.155)\end{array}$ & & & \\
\hline Postgraduate silver-corded (1-yes) & & & $\begin{array}{l}0.586 \\
(0.411)\end{array}$ & & & \\
\hline Working at several HEIs (1-yes) & & & & $\begin{array}{l}-0.303 * \\
(0.143)\end{array}$ & & $\begin{array}{l}-0.289^{*} \\
(0.142)\end{array}$ \\
\hline $\begin{array}{l}\text { Combining teaching and } \\
\text { administrative positions ( } 1 \text {-yes) }\end{array}$ & & & & & $\begin{array}{l}0.396^{*} \\
(0.155)\end{array}$ & $\begin{array}{l}0.353 * \\
(0.154)\end{array}$ \\
\hline Intercept & $\begin{array}{l}3.971 * * * \\
(0.649) \\
\end{array}$ & $\begin{array}{l}3.548 * * * \\
(0.622) \\
\end{array}$ & $\begin{array}{l}3.876 * * * \\
(0.654) \\
\end{array}$ & $\begin{array}{l}4.033 * * * \\
(0.677) \\
\end{array}$ & $\begin{array}{l}3.989 * * * * \\
(0.638) \\
\end{array}$ & $\begin{array}{l}3.668 * * * \\
(0.642) \\
\end{array}$ \\
\hline $\mathrm{R}^{2}$ & 0.245 & 0.267 & 0.251 & 0.257 & 0.261 & 0.293 \\
\hline
\end{tabular}




\begin{tabular}{lllllll}
$F$ & 10.817 & 9.887 & 9.102 & 10.342 & 10.575 & 9.424 \\
$p$ & $<.001$ & $<.001$ & $<.001$ & $<.001$ & $<.001$ & $<.001$ \\
AIC & 972.420 & 967.099 & 973.750 & 969.458 & 967.668 & 960.171 \\
VIF ranged & $1.06-1.75$ & $1.06-1.77$ & $1.07-1.76$ & $1.07-1.76$ & $1.06-1.77$ & $1.07-1.81$ \\
$N$ & 310 & 310 & 310 & 310 & 310 & 310 \\
\hline
\end{tabular}

Note. The table shows the unstandardized coefficients. Robust standard errors in parentheses. VIF - variance inflation factor. * $-p<.05, * *-p<.01, * * *-p<.001$.

Table 4. Predictors of the continuance commitment.

\begin{tabular}{|c|c|c|c|c|c|c|}
\hline & Model 7 & Model 8 & Model 9 & Model 10 & Model 11 & Model 12 \\
\hline Gender (1-male) & $\begin{array}{l}-0.263 \\
(0.160)\end{array}$ & $\begin{array}{l}-0.267 \\
(0.162)\end{array}$ & $\begin{array}{l}-0.277 \\
(0.160)\end{array}$ & $\begin{array}{l}-0.243 \\
(0.160)\end{array}$ & $\begin{array}{l}-0.260 \\
(0.160)\end{array}$ & $\begin{array}{l}-0.243 \\
(0.162)\end{array}$ \\
\hline Age & $\begin{array}{l}0.010 \\
(0.008)\end{array}$ & $\begin{array}{l}0.010 \\
(0.008)\end{array}$ & $\begin{array}{l}0.011 \\
(0.009)\end{array}$ & $\begin{array}{l}0.012 \\
(0.008)\end{array}$ & $\begin{array}{l}0.010 \\
(0.008)\end{array}$ & $\begin{array}{l}0.012 \\
(0.008)\end{array}$ \\
\hline Professor (1-yes) & $\begin{array}{l}-0.257 \\
(0.258)\end{array}$ & $\begin{array}{l}-0.254 \\
(0.259)\end{array}$ & $\begin{array}{l}-0.270 \\
(0.262)\end{array}$ & $\begin{array}{l}-0.229 \\
(0.257)\end{array}$ & $\begin{array}{l}-0.231 \\
(0.263)\end{array}$ & $\begin{array}{l}-0.196 \\
(0.265)\end{array}$ \\
\hline Associate professor (1-yes) & $\begin{array}{l}0.133 \\
(0.201)\end{array}$ & $\begin{array}{l}0.141 \\
(0.202)\end{array}$ & $\begin{array}{l}0.119 \\
(0.201)\end{array}$ & $\begin{array}{l}0.177 \\
(0.204)\end{array}$ & $\begin{array}{l}0.139 \\
(0.202)\end{array}$ & $\begin{array}{l}0.197 \\
(0.207)\end{array}$ \\
\hline Job satisfaction & $\begin{array}{l}-0.571 * * * \\
(0.116)\end{array}$ & $\begin{array}{l}-0.560 * * * \\
(0.118)\end{array}$ & $\begin{array}{l}-0.554 * * * \\
(0.117)\end{array}$ & $\begin{array}{l}-0.575^{* * * *} \\
(0.115)\end{array}$ & $\begin{array}{l}-0.557 * * * \\
(0.118)\end{array}$ & $\begin{array}{l}-0.546^{* * *} \\
(0.118)\end{array}$ \\
\hline Role conflict & $\begin{array}{l}0.203^{*} \\
(0.087)\end{array}$ & $\begin{array}{l}0.208^{*} \\
(0.088)\end{array}$ & $\begin{array}{l}0.212^{*} \\
(0.088)\end{array}$ & $\begin{array}{l}0.204^{*} \\
(0.086)\end{array}$ & $\begin{array}{l}0.217^{*} \\
(0.089)\end{array}$ & $\begin{array}{l}0.227 * \\
(0.089)\end{array}$ \\
\hline $\begin{array}{l}\text { University status }(1- \\
\text { federal/national research) }\end{array}$ & $\begin{array}{l}-0.049 \\
(0.178\end{array}$ & $\begin{array}{l}-0.050 \\
(0.179)\end{array}$ & $\begin{array}{l}-0.049 \\
(0.178)\end{array}$ & $\begin{array}{l}-0.066 \\
(0.180)\end{array}$ & $\begin{array}{l}-0.054 \\
(0.180)\end{array}$ & $\begin{array}{l}-0.077 \\
(0.182)\end{array}$ \\
\hline $\begin{array}{l}\text { University location (1-Moscow or } \\
\text { St. Petersburg) }\end{array}$ & $\begin{array}{l}0.222 \\
(0.175)\end{array}$ & $\begin{array}{l}0.252 \\
(0.179)\end{array}$ & $\begin{array}{l}0.237 \\
(0.175)\end{array}$ & $\begin{array}{l}0.244 \\
(0.174)\end{array}$ & $\begin{array}{l}0.223 \\
(0.175)\end{array}$ & $\begin{array}{l}0.279 \\
(0.178)\end{array}$ \\
\hline Mean USE & $\begin{array}{l}0.005 \\
(0.007)\end{array}$ & $\begin{array}{l}0.005 \\
(0.007)\end{array}$ & $\begin{array}{l}0.005 \\
(0.007)\end{array}$ & $\begin{array}{l}0.005 \\
(0.007)\end{array}$ & $\begin{array}{l}0.005 \\
(0.007)\end{array}$ & $\begin{array}{l}0.004 \\
(0.007)\end{array}$ \\
\hline Undergraduate inbred (1-yes) & & $\begin{array}{l}0.067 \\
(0.175)\end{array}$ & & & & $\begin{array}{l}0.064 \\
(0.178)\end{array}$ \\
\hline $\begin{array}{l}\text { Undergraduate silver-corded (1- } \\
\text { yes) }\end{array}$ & & $\begin{array}{l}0.261 \\
(0.380)\end{array}$ & & & & $\begin{array}{l}0.294 \\
(0.376)\end{array}$ \\
\hline Postgraduate inbred (1-yes) & & & $\begin{array}{l}0.025 \\
(0.198)\end{array}$ & & & \\
\hline Postgraduate silver-corded (1-yes) & & & $\begin{array}{l}0.527 \\
(0.492)\end{array}$ & & & \\
\hline Working at several HEIs (1-yes) & & & & $\begin{array}{l}-0.231 \\
(0.176)\end{array}$ & & $\begin{array}{l}-0.256 \\
(0.177)\end{array}$ \\
\hline $\begin{array}{l}\text { Combining teaching and } \\
\text { administrative positions ( } 1-\text { yes) }\end{array}$ & & & & & $\begin{array}{l}-0.152 \\
(0.177)\end{array}$ & $\begin{array}{l}-0.179 \\
(0.178)\end{array}$ \\
\hline Intercept & $\begin{array}{l}3.873 * * * \\
(0.780)\end{array}$ & $\begin{array}{l}3.756 * * * \\
(0.804)\end{array}$ & $\begin{array}{l}3.729 * * * \\
(0.789)\end{array}$ & $\begin{array}{l}3.921 * * * \\
(0.769)\end{array}$ & $\begin{array}{l}3.866 * * * \\
(0.778)\end{array}$ & $\begin{array}{l}3.795 * * * \\
(0.789)\end{array}$ \\
\hline $\mathrm{R}^{2}$ & 0.133 & 0.135 & 0.136 & 0.139 & 0.135 & 0.144 \\
\hline$F$ & 5.105 & 4.225 & 4.279 & 4.809 & 4.657 & 3.825 \\
\hline$p$ & $<.001$ & $<.001$ & $<.001$ & $<.001$ & $<.001$ & $<.001$ \\
\hline AIC & 1075.772 & 1079.014 & 1078.478 & 1075.709 & 1077.069 & 1079.801 \\
\hline VIF ranged & $1.06-1.75$ & $1.06-1.77$ & $1.07-1.76$ & $1.07-1.76$ & $1.06-1.77$ & $1.07-1.81$ \\
\hline$N$ & 310 & 310 & 310 & 310 & 310 & 310 \\
\hline
\end{tabular}

Note. The table shows the unstandardized coefficients. Robust standard errors in parentheses. VIF - variance inflation factor. * $-p<.05, * *-p<.01, * * *-p<.001$. 
Table 5. Predictors of the normative commitment.

\begin{tabular}{|c|c|c|c|c|c|c|}
\hline & Model 13 & Model 14 & Model 15 & Model 16 & Model 17 & Model 18 \\
\hline Gender (1-male) & $\begin{array}{l}-0.035 \\
(0.166)\end{array}$ & $\begin{array}{l}-0.042 \\
(0.164)\end{array}$ & $\begin{array}{l}-0.040 \\
(0.165)\end{array}$ & $\begin{array}{l}-0.022 \\
(0.168)\end{array}$ & $\begin{array}{l}-0.039 \\
(0.165)\end{array}$ & $\begin{array}{l}-0.036 \\
(0.166)\end{array}$ \\
\hline Age & $\begin{array}{l}0.009 \\
(0.009)\end{array}$ & $\begin{array}{l}0.012 \\
(0.009)\end{array}$ & $\begin{array}{l}0.011 \\
(0.009)\end{array}$ & $\begin{array}{l}0.010 \\
(0.009)\end{array}$ & $\begin{array}{l}0.010 \\
(0.009)\end{array}$ & $\begin{array}{l}0.013 \\
(0.009)\end{array}$ \\
\hline Professor (1-yes) & $\begin{array}{l}0.005 \\
(0.286)\end{array}$ & $\begin{array}{l}0.080 \\
(0.289)\end{array}$ & $\begin{array}{l}0.010 \\
(0.287)\end{array}$ & $\begin{array}{l}0.023 \\
(0.287)\end{array}$ & $\begin{array}{l}-0.031 \\
(0.290)\end{array}$ & $\begin{array}{l}0.061 \\
(0.293)\end{array}$ \\
\hline Associate professor (1-yes) & $\begin{array}{l}-0.385 * \\
(0.171)\end{array}$ & $\begin{array}{l}-0.313 \\
(0.174)\end{array}$ & $\begin{array}{l}-0.392 * \\
(0.171)\end{array}$ & $\begin{array}{l}-0.356^{*} \\
(0.181)\end{array}$ & $\begin{array}{l}-0.395 * \\
(0.172)\end{array}$ & $\begin{array}{l}-0.305 \\
(0.183)\end{array}$ \\
\hline Job satisfaction & $\begin{array}{l}0.448 * * * \\
(0.125)\end{array}$ & $\begin{array}{l}0.448 * * * \\
(0.123)\end{array}$ & $\begin{array}{l}0.454 * * * \\
(0.128)\end{array}$ & $\begin{array}{l}0.445 * * * \\
(0.125)\end{array}$ & $\begin{array}{l}0.428 * * * \\
(0.128)\end{array}$ & $\begin{array}{l}0.433^{* * * *} \\
(0.125)\end{array}$ \\
\hline Role conflict & $\begin{array}{l}-0.146 \\
(0.091)\end{array}$ & $\begin{array}{l}-0.163 \\
(0.089)\end{array}$ & $\begin{array}{l}-0.147 \\
(0.092)\end{array}$ & $\begin{array}{l}-0.145 \\
(0.091)\end{array}$ & $\begin{array}{l}-0.166 \\
(0.092)\end{array}$ & $\begin{array}{l}-0.175 \\
(0.090)\end{array}$ \\
\hline $\begin{array}{l}\text { University status }(1- \\
\text { federal/national research) }\end{array}$ & $\begin{array}{l}-0.308 \\
(0.179)\end{array}$ & $\begin{array}{l}-0.282 \\
(0.177)\end{array}$ & $\begin{array}{l}-0.307 \\
(0.178)\end{array}$ & $\begin{array}{l}-0.319 \\
(0.178)\end{array}$ & $\begin{array}{l}-0.300 \\
(0.180)\end{array}$ & $\begin{array}{l}-0.286 \\
(0.177)\end{array}$ \\
\hline $\begin{array}{l}\text { University location (1-Moscow or } \\
\text { St. Petersburg) }\end{array}$ & $\begin{array}{l}-0.448^{*} \\
(0.191)\end{array}$ & $\begin{array}{l}-0.390^{*} \\
(0.194)\end{array}$ & $\begin{array}{l}-0.436^{*} \\
(0.190)\end{array}$ & $\begin{array}{l}-0.433 * \\
(0.196)\end{array}$ & $\begin{array}{l}-0.448 * \\
(0.192)\end{array}$ & $\begin{array}{l}-0.383 \\
(0.198)\end{array}$ \\
\hline Mean USE & $\begin{array}{l}0.017 * \\
(0.007)\end{array}$ & $\begin{array}{l}0.017 * * \\
(0.007)\end{array}$ & $\begin{array}{l}0.017 * \\
(0.007)\end{array}$ & $\begin{array}{l}0.016 * \\
(0.007)\end{array}$ & $\begin{array}{l}0.017 * \\
(0.007)\end{array}$ & $\begin{array}{l}0.017 * \\
(0.007)\end{array}$ \\
\hline Undergraduate inbred (1-yes) & & $\begin{array}{l}0.402 * \\
(0.173)\end{array}$ & & & & $\begin{array}{l}0.376 * \\
(0.179)\end{array}$ \\
\hline $\begin{array}{l}\text { Undergraduate silver-corded (1- } \\
\text { yes) }\end{array}$ & & $\begin{array}{l}-0.023 \\
(0.344)\end{array}$ & & & & $\begin{array}{l}-0.002 \\
(0.353)\end{array}$ \\
\hline Postgraduate inbred (1-yes) & & & $\begin{array}{l}0.134 \\
(0.179)\end{array}$ & & & \\
\hline Postgraduate silver-corded (1-yes) & & & $\begin{array}{l}0.287 \\
(0.544)\end{array}$ & & & \\
\hline Working at several HEIs (1-yes) & & & & $\begin{array}{l}-0.151 \\
(0.186)\end{array}$ & & $\begin{array}{l}-0.100 \\
(0.189)\end{array}$ \\
\hline $\begin{array}{l}\text { Combining teaching and } \\
\text { administrative positions ( } 1-\text { yes) }\end{array}$ & & & & & $\begin{array}{l}0.214 \\
(0.177)\end{array}$ & $\begin{array}{l}0.150 \\
(0.181)\end{array}$ \\
\hline Intercept & $\begin{array}{l}1.326 \\
(0.790)\end{array}$ & $\begin{array}{l}0.969 \\
(0.788)\end{array}$ & $\begin{array}{l}1.162 \\
(0.821)\end{array}$ & $\begin{array}{l}1.358 \\
(0.798)\end{array}$ & $\begin{array}{l}1.336 \\
(0.789)\end{array}$ & $\begin{array}{l}1.015 \\
(0.801)\end{array}$ \\
\hline $\mathrm{R}^{2}$ & 0.108 & 0.125 & 0.111 & 0.111 & 0.112 & 0.128 \\
\hline$F$ & 4.050 & 3.879 & 3.370 & 3.725 & 3.778 & 3.354 \\
\hline$p$ & $<.001$ & $<.001$ & $<.001$ & $<.001$ & $<.001$ & $<.001$ \\
\hline AIC & 1088.799 & 1086.866 & 1091.999 & 1089.953 & 1089.458 & 1089.752 \\
\hline VIF ranged & $1.06-1.75$ & $1.06-1.77$ & $1.07-1.76$ & $1.07-1.76$ & $1.06-1.77$ & $1.07-1.81$ \\
\hline$N$ & 310 & 310 & 310 & 310 & 310 & 310 \\
\hline
\end{tabular}

Note. The table shows the unstandardized coefficients. Robust standard errors in parentheses. VIF - variance inflation factor. $*$ $-p<.05, * *-p<.01, * * *-p<.001$. 


\section{Discussion and Conclusion}

The main goal of this study was the exploration of specific antecedents of the commitment of faculty to their university, such as academic inbreeding, working at several HEIs, and combining teaching and administrative positions. Several conclusions can be made based on the results of this study. Firstly, being an undergraduate silver-corded faculty, working at the same university from which one graduated, predicts affective commitment, whereas being an undergraduate inbred predicts normative commitment to this university. Undergraduate silver-corded faculty feel a stronger emotional attachment, but undergraduate inbreds feel moral obligations to their institution more so than non-inbreds. However, being an undergraduate inbred does not predict continuance commitment. They do not perceive their costs associated with leaving the organization as greater than those of non-inbreds. It means that neither inbreds nor silver-corded faculty perceive themselves as less competitive compared to non-inbreds. These results are indirect proof of the influence of a specific hiring process on inbreds' perception of the relationships with their HEI. It seems that they really feel obligations toward the university for the opportunity to start an academic career and take their first steps in their socialization within their profession.

Secondly, there is only an effect for undergraduate inbreeding, not for postgraduate inbreeding. A potential reason for this could be specific aspects of postgraduate schools in Russia. Doctoral students are often not fully included in academia and do not go through real professional socialization in their institution. There are several reasons for this (Enikeeva, 2010). The great majority of doctoral students do not have regular and systematic classes. Due to an extremely low level of scholarships, most doctoral student need to have a job, which often is not related to their research. Thus, the inbreds' basis for their commitment to the university probably forms during the studying process, when they learned and began to share the values, standards, and goals of the university and the local academic community. Time spent in doctoral school probably does not have such an influence on faculty commitment toward their university. 
Therefore, undergraduate inbreds can be predisposed to being affectively committed to their university whereas postgraduate inbreds are not.

On the one hand, the current results showing a positive (although not robust) relationship between academic inbreeding and affective commitment can be interpreted as a positive characteristic of the academic inbreeding practice, as more-committed employees are more involved in their job, more frequently perform organizational citizenship behaviour, have stronger intentions to stay and greater wellbeing (Cooper-Hakim \& Viswesvaran, 2005; Mathieu \& Zajac, 1990; Meyer \& Maltin, 2010; Meyer et al., 2002). On the other hand, these results do not compensate for a potential negative consequences of academic inbreeding, such as focusing on the intra-university academic community, lower mobility and collaboration with academics from outside one's own university (Horta, Veloso, \& Grediaga, 2010; Sivak \& Yudkevich, 2015).

Thirdly, the results show that having a post at another higher education institution predicts affective commitment. This difference can be explained in at least two ways. On the one hand, as noted above, working in several HEIs is common practice in Russia because of low wages; a low salary level may be the cause for both working in several HEIs and for a low affective commitment. Pay satisfaction is considered as one of the facets of job satisfaction (Spector, 1997), and job satisfaction and pay satisfaction are stronger correlates of affective commitment (Meyer et al., 2002). It is worth noting that meta-analysis (Judge, Piccolo, Podsakoff, Shaw, \& Rich, 2010) has shown that pay level is weakly related to overall job satisfaction. However, faculty in Russia have the lowest salaries (Altbach et al., 2012), and this may be the cause for a stronger relationship between pay satisfaction and overall job satisfaction. Thus, low income and the need to have additional work are obviously systemic barriers for the development of a psychological attachment to a university. On the other hand, the HEIs in which faculty work may be quite different. Differences can occur in goals, values, priorities, visions about the future, etc. Membership of a professional organization affects its own individual identity (Ashforth \& Johnson, 2003; Becker, 1992) and challenges emotional attachment to each of them, because it is based largely on the perception of 
similarity with the group, sharing its goals and values (Edwards, 2005). It is difficult to identify with two organizations if they have different or even contradictory values, goals, or norms.

Fourthly, results of the current research show that faculty who combine teaching and administrative positions at the same university are more affectively committed. Results also show that this relationship is mediated by role conflict. Combining several positions leads to higher affective commitment, and, at the same time, to perceived role conflict. Therefore perceived role conflict challenges the affective commitment of faculty. However, the direct positive effect of combining teaching and administrative positions on affective commitment was stronger than the indirect negative effect. There are several explanations as to why role conflict can be a threat to affective commitment. The role of an administrator does not match and can even contradict the role of a lecturer. Perhaps this leads to the fact that the university starts to be perceived as more diverse and heterogeneous. It is difficult to identify with a less homogeneous group (Riketta \& Van Dick, 2005; Van Knippenberg \& Van Schie, 2000) and remain committed to the university as whole. Cooper, Dewe, and O'Driscoll (2001) suggest that role conflict leads to psychological strain; such psychological strain may decrease employees' affective organizational commitment. This psychological strain's mediation effect should be tested in future research. It means universities' management should create an environment that will reduce the likelihood of role conflict. Universities should not appoint administrators based only on scholarly performance, and should provide workshops, seminars, and courses that help faculty obtain the knowledge and skills required for administrative work. Time-management is especially important in this case. Universities should help faculty to realize that to be effective administrators they must sacrifice teaching and research time. Also, management must take into account the fact of combining different roles in the process of performance evaluation. This may be achieved by an effective contract, which divides teaching and administrating more formally (by time and load). Finally, it seems that universities should provide assistants for highlevel administrators who combine teaching, administration, and research. 


\section{References}

Abrams, D., Ando, K., \& Hinkle, S. (1998). Psychological Attachment to the Group: Cross-Cultural Differences in Organizational Identification and Subjective Norms as Predictors of Workers' Turnover Intentions. Personality and Social Psychology Bulletin, 24(10), 1027-1039. http://doi.org/10.1177/01461672982410001

Adkins, C. L., Werbel, J. D., \& Farh, J.-L. (2001). A Field Study of Job Insecurity during a Financial Crisis. Group \& Organization Management, 26(4), 463-483. http://doi.org/10.1177/1059601101264004

Allen, N. J., \& Meyer, J. P. (1990). The measurement and antecedents of affective, continuance and normative commitment to the organization. Journal of Occupational Psychology, 63(1), 1-18. http://doi.org/10.1111/j.2044-8325.1990.tb00506.x

Altbach, P. G., Reisberg, L., Yudkevich, M., Androushchak, G., \& Pacheco, I. F. (2012). Paying the Professoriate: A Global Comparison of Compensation and Contracts. Taylor \& Francis.

Ambrose, M. L., \& Cropanzano, R. (2003). A longitudinal analysis of organizational fairness: An examination of reactions to tenure and promotion decisions. Journal of Applied Psychology, 88(2), 266-275. http://doi.org/10.1037/0021-9010.88.2.266

Ashforth, B. E., Harrison, S. H., \& Corley, K. G. (2008). Identification in Organizations: An Examination of Four Fundamental Questions. Journal of Management, 34(3), 325-374. http://doi.org/10.1177/0149206308316059

Ashforth, B. E., \& Johnson, S. A. (2003). Which Hat to Wear?: The Relative Salience of Multiple Identities in Organizational Contexts. In M. A. Hogg \& D. J. Terry (Eds.), Social Identity Processes in Organizational Contexts (pp. 31-48). Hove UK: Psychology Press.

Baldridge, J. V. (1983). Organizational characteristics of colleges and universities. In J. V. Baldridge \& T. Deal (Eds.), The dynamics of organizational change in education (pp. 38-59). Berkeley: McCutchan Publishing Corporation.

Becker, T. E. (1992). Foci and Bases of Commitment: Are They Distinctions Worth Making? Academy of Management Journal, 35(1), 232-244. http://doi.org/10.2307/256481

Berelson, B. (1960). Graduate Education in the United States. New York: McGraw Hill.

Chughtai, A. A., \& Zafar, S. (2006). Antecedents and Consequences of Organizational Commitment Among Pakistani University Teachers. Applied Human Resource Management Research, 11(1), 3964.

Cooper, C. L., Dewe, P. J., \& O’Driscoll, M. P. (2001). Organizational stress: A review and critique of theory, research, and applications. Sage Publications.

Cooper-Hakim, A., \& Viswesvaran, C. (2005). The construct of work commitment: testing an integrative framework. Psychological Bulletin, 131(2), 241-59. http://doi.org/10.1037/0033-2909.131.2.241

Dallner, A., Elo, A.-L., Gambrele, F., Hottinen, V., Knardahl, S., Linstrom, K., ... Orhede, E. (2000). Validation of the General Nordic Questionnaire for Psychological and Social Factors at Work. Nordic Council of Ministers Copenhagen, DK. Nord.

Daly, C. J., \& Dee, J. R. (2006). Greener Pastures: Faculty Turnover Intent in Urban Public Universities. The Journal of Higher Education, 77(5), 776-803. http://doi.org/10.1353/jhe.2006.0040 
Duderstadt, J. J. (2001). Fire, Ready, Aim! University Decision-Making During an Era of Rapid Change. In W. Z. Hirsch \& L. E. Weber (Eds.), Governance in Higher Education: The University in a State of Flux (pp. 26-51). London: Economica.

Edwards, M. R. (2005). Organizational identification: A conceptual and operational review. International Journal of Management Reviews, 7(4), 207-230. http://doi.org/10.1111/j.1468-2370.2005.00114.x

Eisenberg, T., \& Wells, M. T. (2000). Inbreeding in Law School Hiring: Assessing the Performance of Faculty Hired from Within. The Journal of Legal Studies, 29(S1), 369-388. http://doi.org/10.1086/468077

Eisinga, R., Teelken, C., \& Doorewaard, H. (2010). Assessing Cross-National Invariance of the ThreeComponent Model of Organizational Commitment: A Six-Country Study of European University Faculty. Cross-Cultural Research, 44(4), 341-373. http://doi.org/10.1177/1069397110370932

Enikeeva, A. (2010). Problemy rossijskoj aspirantury (The problems of the Russian postgraduate school). Nauka I Tehnologii Rossii - STRF.ru. Retrieved from http://www.strf.ru/material.aspx?CatalogId=221\&d_no=34750\#.VtSyshjUAnk

Euben, D. R. (2004). Faculty Employment Outside of the University: Conflicts of Commitment. In Presentation to the National Association of College and University Attorneys. Atlanta, Georgia. Retrieved from http://www.aaup.org/issues/resources-conflicts-interest/outside-university-conflicts

Fuller, J. B., Hester, K., Barnett, T., \& Relyea, L. F. C. (2006). Perceived Organizational Support and Perceived External Prestige: Predicting Organizational Attachment for University Faculty, Staff, and Administrators. The Journal of Social Psychology, 146(3), 327-347. http://doi.org/10.3200/SOCP.146.3.327-347

Gmelch, W. H., \& Burns, J. S. (1994). Sources of Stress for Academic Department Chairpersons. Journal of Educational Administration, 32(1), 79-94. http://doi.org/10.1108/09578239410051862

Gorelova, O., \& Yudkevich, M. (2015). Academic Inbreeding: State of the Literature. In M. Yudkevich, P. G. Altbach, \& L. E. Rumbley (Eds.), Academic Inbreeding and Mobility in Higher Education. Global Perspaectives (pp. 17-45). Palgrave Macmillan.

Gormley, D. K., \& Kennerly, S. (2010). Influence of Work Role and Perceptions of Climate on Faculty Organizational Commitment. Journal of Professional Nursing, 26(2), 108-115. http://doi.org/10.1016/j.profnurs.2009.11.001

Gutierrez, A. P., Candela, L. L., \& Carver, L. (2012). The structural relationships between organizational commitment, global job satisfaction, developmental experiences, work values, organizational support, and person-organization fit among nursing faculty. Journal of Advanced Nursing, 68(7), 1601-1614. http://doi.org/10.1111/j.1365-2648.2012.05990.x

Hancock, T. M. (2007). The business of universities and the role of department chair. International Journal of Educational Management, 21(4), 306-314. http://doi.org/10.1108/09513540710749528

Horta, H. (2013). Deepening our understanding of academic inbreeding effects on research information exchange and scientific output: new insights for academic based research. Higher Education, 65(4), 487-510. http://doi.org/10.1007/s10734-012-9559-7

Horta, H., Sato, M., \& Yonezawa, A. (2011). Academic inbreeding: exploring its characteristics and rationale in Japanese universities using a qualitative perspective. Asia Pacific Education Review, 12(1), 35-44. http://doi.org/10.1007/s12564-010-9126-9

Horta, H., Veloso, F. M., \& Grediaga, R. (2010). Navel Gazing: Academic Inbreeding and Scientific 
Productivity. Management Science, 56(3), 414-429. http://doi.org/10.1287/mnsc.1090.1109

Horta, H., \& Yudkevich, M. (2015). The role of academic inbreeding in developing higher education systems: Challenges and possible solutions. Technological Forecasting and Social Change. http://doi.org/10.1016/j.techfore.2015.06.039

Jing, L., \& Zhang, D. (2014). The mediation of performance in the relationship of organizational commitment to university faculty's effectiveness. Asia Pacific Education Review, 15(1, SI), 141-153. http://doi.org/10.1007/s12564-013-9309-2

Judge, T. A., Piccolo, R. F., Podsakoff, N. P., Shaw, J. C., \& Rich, B. L. (2010). The relationship between pay and job satisfaction: A meta-analysis of the literature. Journal of Vocational Behavior, 77(2), 157-167. http://doi.org/10.1016/j.jvb.2010.04.002

Kozmina, Y. (2014). Preferences of Professors about Research and Teaching. Voprosy Obrazovaniya/ Educational Studies. Moscow, (3), 135-151. http://doi.org/10.17323/1814-9545-2014-3-135-151

Li, Y. (2014). Building affective commitment to organization among Chinese university teachers: the roles of organizational justice and job burnout. Educational Assessment, Evaluation and Accountability, 26(2), 135-152. http://doi.org/10.1007/s11092-014-9192-3

Marchiori, D. M., \& Henkin, A. B. (2004). Organizational commitment of a health profession faculty: dimensions, correlates and conditions. Medical Teacher, 26(4), 353-358. http://doi.org/10.1080/01421590410001683221

Mathieu, J. E., \& Zajac, D. M. (1990). A Review and Meta-Analysis of the Antecedents, Correlates, and Consequences of Organizational Commitment. Psychological Bulletin, 108(2), 171-194.

Meyer, J. P., \& Maltin, E. R. (2010). Employee commitment and well-being: A critical review, theoretical framework and research agenda. Journal of Vocational Behavior, 77(2), 323-337. http://doi.org/10.1016/j.jvb.2010.04.007

Meyer, J. P., Stanley, D. J., Herscovitch, L., \& Topolnytsky, L. (2002). Affective, Continuance, and Normative Commitment to the Organization: A Meta-analysis of Antecedents, Correlates, and Consequences. Journal of Vocational Behavior, 61(1), 20-52. http://doi.org/10.1006/jvbe.2001.1842

Morichika, N., \& Shibayama, S. (2015). Impact of inbreeding on scientific productivity: A case study of a Japanese university department. Research Evaluation, 24(2), 146-157. http://doi.org/10.1093/reseval/rvv002

Mowday, R. T., Porter, L. W., \& Steers, R. M. (1982). Employee-Organization Linkages: The Psychology of Commitment, Absenteeism, and Turnover. New York: Academic Press.

Musselin, C. (2013). Redefinition of the relationships between academics and their university. Higher Education, 65(1), 25-37. http://doi.org/10.1007/s10734-012-9579-3

Neumann, Y., \& Finaly-Neumann, E. (1990). The reward-support framework and faculty commitment to their university. Research in Higher Education, 31(1), 75-97. http://doi.org/10.1007/bf00992558

O'Reilly, C., \& Chatman, J. (1986). Organizational Commitment and Psychological Attachment: The Effects of Compliance, Identification, and Internalization on Prosocial Behavior. Journal of Applied Psychology, 71(3), 492-499. http://doi.org/10.1037/0021-9010.71.3.492

R Core Team, D. (2015). R: A language and environment for statistical computing. R Foundation for Statistical Computing, Vienna, Austria. Retrieved from http://www.r-project.org/

Riketta, M. (2005). Organizational identification: A meta-analysis. Journal of Vocational Behavior, 66(2), 
358-384. http://doi.org/10.1016/j.jvb.2004.05.005

Riketta, M., \& Van Dick, R. (2005). Foci of attachment in organizations: A meta-analytic comparison of the strength and correlates of workgroup versus organizational identification and commitment.

Journal of Vocational Behavior, 67(3), 490-510. http://doi.org/10.1016/j.jvb.2004.06.001

Rizzo, J. R., House, R. J., \& Lirtzman, S. I. (1970). Role Conflict and Ambiguity in Complex

Organizations. Administrative Science Quarterly, 15(2), 150-162. http://doi.org/10.2307/2391486

Roschina, Y. M., \& Filippova, T. N. (2006). Prepodavateli na ryinke obrazovatelnyih uslug. Monitoring Ekonomiki Obrazovaniya. Inf. Byulleten, 2(20), 1-30. (in Russian).

Schulz, J. (2013). The impact of role conflict, role ambiguity and organizational climate on the job satisfaction of academic staff in research-intensive universities in the UK. Higher Education Research \& Development, 32(3), 464-478. http://doi.org/10.1080/07294360.2012.680209

Shattock, M. (2014). Can we still speak of there being an academic profession? History of Education, 43(6), 727-739. http://doi.org/10.1080/0046760X.2014.964008

Sinclair, R. R., Martin, J. E., \& Michel, R. P. (1999). Full-Time and Part-Time Subgroup Differences in Job Attitudes and Demographic Characteristics. Journal of Vocational Behavior, 55(3), 337-357. http://doi.org/10.1006/jvbe.1999.1686

Sivak, E., \& Yudkevich, M. (2015). Academic Immobility and Inbreeding in Russian university sector. In M. Yudkevich, P. G. Altbach, \& L. E. Rumbley (Eds.), Academic Inbreeding and Mobility in Higher Education. Global Perspaectives (pp. 130-155). Palgrave Macmillan.

Southcombe, A., Fulop, L., Carter, G., \& Cavanagh, J. (2014). Building commitment: an examination of learning climate congruence and the affective commitment of academics in an Australian university. Journal of Further and Higher Education, 1-25. http://doi.org/10.1080/0309877X.2013.869566

Spector, P. E. (1997). Job satisfaction: Application, assessment, causes and consequences. Thousand Oaks, CA: Sage Publications.

Tahir, L., Abdullah, T., Ali, F., \& Daud, K. (2014). Academics transformational leadership: an investigation of heads of department leadership behaviours in Malaysian public universities. Educational Studies, 40(5), 473-495. http://doi.org/10.1080/03055698.2014.932272

Thompson, E. R., \& Phua, F. T. T. (2012). A Brief Index of Affective Job Satisfaction. Group \& Organization Management, 37(3), 275-307. http://doi.org/10.1177/1059601111434201

Van Knippenberg, D., \& Van Schie, E. C. M. (2000). Foci and correlates of organizational identification. Journal of Occupational and Organizational Psychology, 73(2), 137-147. http://doi.org/10.1348/096317900166949

Vázquez-Cupeiro, S., \& Elston, M. A. (2006). Gender and academic career trajectories in Spain: From gendered passion to consecration in a Sistema Endogámico? Employee Relations, 28(6), 588-603. http://doi.org/10.1108/01425450610704515

Wolverton, M., Wolverton, M. L., \& Gmelch, W. H. (1999). The Impact of Role Conflict and Ambiguity on Academic Deans. The Journal of Higher Education, 70(1), 80-106.

http://doi.org/10.2307/2649119

Yudkevich, M. (2014). The Russian University: recovery and rehabilitation. Studies in Higher Education, 39(8), 1463-1474. http://doi.org/10.1080/03075079.2014.949537

Yudkevich, M., Kozmina, Y., Sivak, E., Bain, O., \& Davydova, I. (2013). Changing Academic 
Profession: Russia Country Report. Moscow. 